\title{
Population responses of bird populations to climate change on two continents vary with species' ecological traits but not with direction of change in climate suitability
}

Lucy R. Mason ${ }^{1} \cdot$ Rhys E. Green ${ }^{1,2}$ - Christine Howard ${ }^{3}$ Philip A. Stephens ${ }^{3}$ • Stephen G. Willis ${ }^{3}$ - Ainars Aunins ${ }^{4,5}$. Lluís Brotons ${ }^{6,7,8,9} \cdot$ Tomasz Chodkiewicz $^{10,11}$. Przemysław Chylarecki ${ }^{10}$ - Virginia Escandell ${ }^{12}$ - Ruud P. B. Foppen ${ }^{13,14,15}$. Sergi Herrando ${ }^{6,7}$. Magne Husby ${ }^{16,17}$ • Frédéric Jiguet ${ }^{18}$ • John Atle Kålås ${ }^{19}$. Åke Lindström ${ }^{20}$. Dario Massimino ${ }^{21}$. Charlotte Moshøj ${ }^{22} \cdot$ Renno Nellis $^{23}$. Jean-Yves Paquet ${ }^{24}$ - Jiř́ Reif ${ }^{25}$ • Päivi M. Sirkiä ${ }^{26}$ - Tibor Szép ${ }^{27}$. Guido Tellini Florenzano ${ }^{28} \cdot$ Norbert Teufelbauer $^{29} \cdot$ Sven Trautmann $^{30}$. Arco van Strien ${ }^{31}$ • Chris A. M. van Turnhout ${ }^{13,14}$ • Petr Voříšek ${ }^{32,33}$. Richard D. Gregory ${ }^{1,34}$ (D)

Received: 17 September 2018 / Accepted: 2 September 2019/Published online: 9 October 2019

(C) The Author(s) 2019

\begin{abstract}
Climate change is a major global threat to biodiversity with widespread impacts on ecological communities. Evidence for beneficial impacts on populations is perceived to be stronger and more plentiful than that for negative impacts, but few studies have investigated this apparent disparity, or how ecological factors affect population responses to climatic change. We examined the strength of the relationship between species-specific regional population changes and climate suitability trends (CST), using 30-year datasets of population change for 525 breeding bird species in Europe and the USA. These data indicate a consistent positive relationship between population trend and CST across the two continents. Importantly, we found no evidence that this positive relationship differs between species expected to be negatively and positively impacted across the entire taxonomic group, suggesting that climate change is causing equally strong, quantifiable population increases and declines. Species' responses to changing climatic suitability varied with ecological traits, however, particularly breeding habitat preference and body mass. Species associated with inland wetlands responded most strongly and consistently to recent climatic change. In Europe, smaller species also appeared to respond more strongly, whilst the relationship with body mass was less clear-cut for North American birds. Overall, our results identify the role of certain traits in modulating responses to climate change and emphasise the importance of long-term data on abundance for detecting largescale species' responses to environmental changes.
\end{abstract}




\section{Introduction}

Correlational studies over large numbers of species, regions and taxonomic groups have revealed clear associations between recent climate change and observed changes in geographical range and abundance of many plant and animal taxa (Hickling et al. 2006; Parmesan and Yohe 2003; Spooner et al. 2018; Stephens et al. 2016). The evidence for positive changes in species abundance and distribution in response to beneficial recent climate change (i.e. in regions where this will lead to abundance increases and range extensions) is generally perceived to be stronger and more plentiful than for populations expected to be negatively impacted (e.g. Frishkoff et al. 2016; Parmesan et al. 1999; Parmesan and Yohe 2003; Root et al. 2003; Thomas et al. 2006; Thomas and Lennon 1999). However, this effect may be an artefact, particularly if there are time lags in the responses of populations to climate change, or if range retractions are more difficult to detect than expansions. For example, climate change may adversely affect an animal species through changes in vegetation affecting the suitability of its habitat, which take time to occur, leading to an extinction debt (Kuussaari et al. 2009). Such time lags may act in the opposite direction too, resulting in instances where beneficial effects, and therefore, the responses of species predicted to benefit may be delayed (Menéndez et al. 2006), but this would not explain the suggested excess of positive relative to negative effects on species distribution and population changes.

Range retractions may be more difficult to detect than expansions, particularly when occurrence is mapped at a coarse scale. Range expansion requires successful colonisation of a new site beyond the current range by a small number of individuals, whilst range retraction may require the extinction of many local populations (Thomas et al. 2006; Brommer et al. 2012). Furthermore, the biological process of extinction may constitute a longer-term process than colonisation, which may not be detected in the relatively short time periods considered by many studies of range change (Brommer et al. 2012). Finally, attributing range retractions solely to climatic change is difficult. Range expansion in areas of degraded habitat can easily be attributed to improving climatic conditions. However, apportioning the cause of range retractions among a suite of threatening processes, including habitat degradation and invasive species, is much harder (Thomas et al. 2006). Despite some evidence for the negative effects of climate change on populations (Lehikoinen et al. 2019), there is still no consensus on whether the reported difference in strength and quantity of evidence for positive relative to negative effects of climate change is an artefact or a true reflection of species' responses. A large-scale, multispecies assessment of the positive relative to negative effects of climate change on species' populations would provide important insights into the cause of this apparent disparity.

In some studies investigating the impacts of climate change, species distribution models (SDMs) relating geographical distribution to climatic variables are combined with annual meteorological data to estimate the direction and magnitude of changes in climate suitability over a given time period for different species or regions (Engler et al. 2017; Stephens et al. 2016). Variation in observed population changes, both among species in a given area and among regions for a given species, can then be compared to the modelled differences in climate suitability trend. A positive relationship between observed and expected change is taken as correlational evidence of a probable population-level response of distribution and/or abundance to climatic change (although see Clavero et al. 2011). Such studies have found positive relationships between climate suitability and population trend, as expected, but have also identified substantial residual variation in the observed changes in distribution and abundance that is not accounted for statistically by measures of climatic change (Green et al. 2008; Stephens et al. 2016). 
Species' populations and distributions are influenced by many factors other than climate (e.g. Clavero et al. 2011), and local climate adaptation may lead to different responses in different parts of a species' range (Visser et al. 2003), so such unexplained variation is unsurprising. Ecological factors might lead to interspecific variation in spatial patterns of sensitivity to climatic change, regardless of the expected direction of change in suitability (Pearce-Higgins et al. 2015). The phenological mismatch hypothesis is a good example of this, where the prevalence and magnitude of species' sensitivity to changes in life-cycle phenology relative to the phenology of prey or other resources (Franks et al. 2018) may vary because of differences in habitat, diet or migratory behaviour (Both et al. 2010). Changes, unrelated to climate change, in the suitability of habitats or impacts of environmental factors on demographic rates, such as changes in agricultural practices, land cover or pollution, may also counteract and mask the effects of climate change to a different extent for some groups of species (Clavero et al. 2011; Herrando et al. 2014; Kampichler et al. 2012). However, to our knowledge, the potential role of ecological traits in affecting species' responses to recent climatic change has not been explored comprehensively.

In this paper, we address these two issues - the apparent difference in response between species expected to benefit or be negatively impacted by climate change, and the role of ecological traits in influencing the relationship of population change to climate suitability trend. First, we examine the strength of the relationship between species- and region-specific population trends and trends in climate suitability using two of the best global datasets of recent long-term population changes for 525 bird species from Europe and the USA. Second, we investigate how species' responses to changing climatic suitability vary with ecological traits, specifically body mass, migratory behaviour and habitat association. We hypothesise that, should all three trait variables be upheld as important, we might expect to see a more positive mean annual population trend ( $r$ ) vs. CST regression slope for (i) species with smaller body mass, whose populations are likely to be favoured by the higher temperatures inherent in climatic change (Millien et al. 2006; Sheridan and Bickford 2011); (ii) species associated with habitats more immediately-responsive to climate change (i.e. wetlands), which might be expected to undergo more rapid population changes as a result of climate-driven habitat degradation or improvement (Erwin 2009; Foden et al. 2009) and (iii) long-distance migrants which may be more vulnerable to phenological changes on their breeding grounds (Both et al. 2010; Mayor et al. 2017; Vickery et al. 2014).

\section{Materials and methods}

\subsection{Bird population trends}

We obtained information on changes over time in breeding bird population size in Europe during the period 1980-2009 for 145 common species in 20 nation states (termed 'states' henceforward) from the Pan-European Common Bird Monitoring Scheme (PECBMS 2012; Online Resources 1 and 2). For the USA, information on changes in breeding population size during the same period was obtained for 380 bird species in the 48 states of the contiguous USA (also termed 'states') from the US Breeding Bird Survey (Sauer and Link 2011; Online Resources 3 and 4). For a given species, the information consisted of annual indices of population in the state derived from counts conducted annually using comparable methods at survey sites in all European or all US states. The methods used to derive the annual 
population indices from the count data are given by PECBMS (2012) and Sauer and Link (2011) for Europe and the USA respectively. The number of species for which annual indices was available for a given state ranged from 36 to 104 species (Europe, Online Resource 2) and from 66 to 215 species (USA, Online Resource 4). The duration of the time period of the data series used to calculate a population trend ranged from 10 to 30 years, depending on state and species (Online Resource 5, PECBMS 2012; Sauer and Link 2011).

Datasets were checked to eliminate state-level trends for species that (i) were of limited temporal extent or (ii) displayed anomalously large inter-annual population fluctuations, possibly indicative of extensive population movements among states or of less robust population estimates. To do this, we applied the following rules. First, state-wide indices of abundance for any species were included only if that species had been monitored since 2000 at the latest. Second, state-level abundance index series for any species that displayed population fluctuations too large to reflect local population processes, such as annual changes of a factor > 10, were excluded (Gregory et al. 2009; Stephens et al. 2016). For Europe, this left 1686 species-state combinations with population data available for analysis, with 6760 species-state combinations available for the USA. For each species and state, a mean annual population trend $(r)$ was calculated as the slope of the ordinary least squares regression of the natural logarithm of the population index on calendar year, using the results for all years for which an eligible population index was available (Online Resource 5).

\subsection{Ecological traits}

In examining the relationship between bird population trends and trends in climate suitability, we wished to account for ecological traits of species. We used information on three traits previously reported as important predictors of population trends and for which data could be summarised with a high level of confidence at the state-level for both European and North American species: mean body mass, breeding-season habitat association and migratory behaviour (Angert et al. 2011; Buckley and Kingsolver 2012). These traits are correlated with drivers of population trend (e.g. land-use change; Sanderson et al. 2006), and may act as proxies for other ecological traits (e.g. diet, clutch size, brain size, degree of habitat specialisation; Millien et al. 2006).

Body mass was obtained as the mean of the mean masses of male and female birds (g), or of unsexed birds where sex-specific information was not available. Mass data came from Cramp et al. (1977-1994) for European species, and from BirdLife International's World Bird Database for US species (BirdLife-International 2014). We used the natural logarithm of this mean body mass (Lmass) in analyses (Online Resources 1 and 3).

Species were assigned to one of four breeding-season habitat categories (HAB; Online Resources 1 and 3). For Europe, species were assigned a primary breeding habitat, based on information from PECBMS (2012), Gregory et al. (2009), Tucker and Evans (1997) and expert opinion. For the USA, broad habitat use could not be differentiated at state level, so continent-wide habitat preferences were obtained from BirdLife-International (2014) and Poole (2005). Species were allocated to habitat categories if more than $50 \%$ of the population in each state used that particular habitat during the breeding season (Gregory et al. 2009). Habitat definitions in the sources consulted differed between Europe and the USA, so for comparability between the two continents, we defined our own broad habitat categories as forest, comprising 'forest' 
(Europe) and 'forest and shrubland' (USA) habitats; farmland, comprising 'farmland' (Europe) and 'grassland' (USA) habitats, both of which included arable and grassland; inland wetland, comprising 'wetland' (Europe) and 'inland wetland' (USA) habitats, including rivers, lakes, marshes and other non-marine wetlands and other, comprising all habitats not considered forest, farmland or inland wetland.

Each species in each state was assigned to one of four migratory behaviour categories (MIG; Onlines Resource 1 and 3) classifying the behaviour of all or most individuals: longdistance migrant, short-distance migrant, resident and mixed strategy species (Gregory et al. 2009). For Europe, this was based on the text and maps in Cramp et al. (1977-1994) supplemented by available migration atlases (Speek and Speek 1984; Spina and Volponi 2008-2009; Wernham et al. 2002; Zink and Bairlein 1987-1995). For the USA, we based the classification on maps in Poole (2005). Long-distance migrants were defined as those usually making regular seasonal movements between their breeding range and either, for Europe, a non-breeding range outside the Palaearctic region (Snow and Perrins 1998), or, for the USA, a non-breeding range occurring south of latitude $25^{\circ} \mathrm{N}$ (the southern tip of Florida). We considered short-distance migrants to be those usually making regular migratory or dispersive movements within the Palaearctic region (Europe) or north of latitude $25^{\circ} \mathrm{N}$ (USA). Residents were those where most individuals were non-migratory, making only irregular movements within the Palaearctic region (Europe) or where breeding and nonbreeding ranges overlapped by $>50 \%$ (USA). The mixed strategy category was only used in the USA in instances where information was insufficient to determine where birds from a state migrate to outside the breeding season, although the species was known to migrate to both short- and long-distance destinations in other states.

\subsection{Climate suitability trends}

Climate suitability trends (CST) for each species and state were derived from SDMs (Online Resource 5), which linked annual grid-cell specific probability of occurrence estimates for a given species to grid-cell specific contemporaneous climatic data. Steps involved in fitting SDMs and using them to derive CSTs followed the methods of Stephens et al. (2016), and are described in the following sections.

\subsection{Species occurrence data for SDM fitting}

For European birds, species occurrence data (the presence or absence of each species as a breeding bird) was obtained for Europe, Turkey, Cyprus and North Africa (Mediterranean to latitude $20^{\circ} \mathrm{N}$ ). The latter three regions, representing the southern margin of the Western Palaearctic realm, were added to include the southern range margins of as many species as possible, which was expected to improve the performance of the SDMs (Barbet-Massin et al. 2010). For Europe, occurrence data was available for $50 \times 50 \mathrm{~km}$ UTM squares from Hagemeijer and Blair (1997). Occurrence data for Turkey, Cyprus and North Africa was available for $0.5^{\circ} \times 0.5^{\circ}$ latitude-longitude grid cells (approximately equal to $50 \times 50 \mathrm{~km}$ UTM squares) from BirdLife International Natureserve (2013). For the USA, we used bird species occurrence data for $0.5^{\circ} \times 0.5^{\circ}$ latitude-longitude grid cells spanning the whole of North America northwards from latitude $10^{\circ} \mathrm{N}$ from BirdLife International Natureserve (2013). Occurrence data on both continents was mostly derived from surveys conducted in the $1980 \mathrm{~s}$ before the most rapid phase of recent climate change. 


\subsection{Observed climate data for SDM fitting}

Monthly mean values for cloud cover, precipitation and temperature for the period 1961 to 1990 were obtained from www.worldclim.org (Hijmans et al. 2005) and CRUTS3.1 (Harris et al. 2014). Soil water capacity data were obtained from Prentice et al. (1992). Climate data were bilinearly interpolated onto the same grid structure as used for species occurrence data (50 km UTM grid for Europe; $0.5^{\circ}$ grid for Turkey, Cyprus, North Africa and North America). Bioclimate variables shown elsewhere to be highly influential were derived from climate data following Prentice et al. (1992) and Gregory et al. (2009), and included annual temperature sum above $5{ }^{\circ} \mathrm{C}$ (GDD5), mean temperature of the coldest month (MTCO) and an estimate of the annual ratio of actual to potential evapotranspiration (APET). We restricted the number of bioclimate variables used to minimise the risk of overfitting and data-dredging, which can occur when large numbers of candidate explanatory variables are used in fitting SDMs (Pearce-Higgins and Green 2014). We chose these particular variables because they are known to influence the distribution of plant species and vegetation types and could therefore limit species' ranges directly through effects on species' physiology, or indirectly through effects on vegetation and habitats, or on prey, predators, competitors or diseases (Huntley et al. 2007; Pearce-Higgins and Green 2014).

\subsection{Fitting the SDMs}

For each species, we fitted four types of SDM following Bagchi et al. (2013) to 1980s occurrence data and the 1961-1990 values of the three bioclimate variables. The four SDM types used were generalized linear models (GLMs, McCullagh and Nelder 1989), semiparametric generalized additive models (GAMs, Hastie and Tibshirani 1990), generalized boosted models (GBMs, Elith et al. 2008) and random forests (RFs, Cutler et al. 2007), all of which perform well when compared with other SDM-fitting techniques (Araujo et al. 2005; Elith and Leathwick 2009; Franklin 2009; Meynard and Quinn 2007; Wenger and Olden 2012).

We used a cross-validation approach to fit each type of SDM. The occurrence data used to fit each model was divided into ten similarly-sized blocks each with similar mean values for the three bioclimate variables, but spanning the full range of bioclimates. Blocks comprised spatially disaggregated sampling units consisting of whole or partial global ecoregions (www. worldwildlife.org/science/data). SDMs were fitted to data from nine blocks, excluding each block in turn, with the fitted SDM from each of the ten iterations of this procedure being used, together with grid-cell-specific values of the 1961-1990 bioclimate data to calculate the probability of occupancy for each cell in the left-out block. These predicted probabilities of occupancy were then assembled for the entire area. Full details of model fitting methods, outcomes and measures of goodness-of-fit are presented in Stephens et al. (2016).

\subsection{Calculating CST for 1980-2009}

For a given species and area (Europe or the USA), the ten models fitted using each SDM approach (i.e. the cross-validation models fitted with each block omitted) were applied to annual bioclimate data from all focal states for each of the years 1980-2009. The climatic data used for this were as described for the SDM fitting, but annual values of the bioclimate variables were used, in combination with the SDMs, to calculate annual values of expected 
probability of species occurrence for each grid cell. Predicted probabilities of occurrence were averaged across the ten models for each cell to give the probability of occurrence for that cell in that year from the given SDM method. Probability of occurrence for each cell was then averaged across the four SDM approaches to give an ensemble probability of occurrence for the given cell in the given year. We used an ensemble approach to minimise the influence of potential bias associated with any particular modelling approach (Araújo and New 2007; Araújo et al. 2011; Bagchi et al. 2013). For a given state and year, annual mean probability of occurrence was then averaged across all cells in the state.

For a given species in a given state, the CST was calculated as the slope of an ordinary least squares linear regression of logit annual mean ensemble probability of occurrence (as described above) regressed on calendar year. A positive CST slope indicates an increased probability of occurrence over time (species is predicted to benefit from climate change in that state); a negative slope indicates that the species is predicted to be disadvantaged by climate change. CST was calculated for the same time period over which species-state-specific population trends were calculated, i.e. from 1980 or the first year of population data (whichever was later) to 2009 or the year after which there was no further data (whichever was earlier, Online Resource 5).

\subsection{Statistical analysis}

The principal objective of our analysis was to examine the relationship between observed recent population trends $(r)$ and trends in climate suitability (CST) at the species-state level for each continent. We had an a priori expectation that $r$ was positively related to CST (Green et al. 2008), and wished to examine firstly whether the strength of this relationship differed between species-states for which climate suitability was expected to decrease (CST-) or increase (CST+ ), and secondly whether species- and state-specific ecological traits affected the strength of this relationship.

\subsection{Population trend vs. CST relationships for species-states expected to be positively or negatively impacted by climate change}

To test whether responses to climate change differ between species-state combinations in which populations were expected to benefit from recent observed climate change (i.e. all species with a positive CST [CST+, Online Resources 1-4]) and those expected to be adversely affected (i.e. all species with a negative CST [CST-, Online Resources 1-4]), we compared the slope of the regression of $r$ on CST for these two species-state groups separately through piecewise regression, assuming that the slope of the relationship would change at $\mathrm{CST}=0$. Linear mixed models (LMMs) were fitted using the lme4 package in R (Bates and Maechler 2009; R Core Team 2013) for Europe and the USA separately, incorporating the crossed random effects of species and state, thus accounting for the non-independence of trends among states within species, and among species within states. We also included random effects of the interactions between species and CST and between state and CST, to account for the non-independence of the relationship between $r$ and CST among populations of a species and between states, and a nested random effect of 'order/family/species' to account for potential phylogenetic non-independence. Our data would not support the fitting of random coefficient terms. For all models, diagnostic plots were used to check that assumptions had been met. 
A piecewise test was incorporated into models by including both CST and also the dummy variable CST*, where CST $* 0$ if CST $<0$ (CST- species-states) and $\mathrm{CST}^{*}=\mathrm{CST}$ if CST $\geq 0$ (CST+ species-states; Hardy 1993). The regression coefficient for CST* represents the estimated difference in slope between the CST- $(\mathrm{CST}<0)$ and CST $+(\mathrm{CST} \geq 0)$ sections of the CST range. We took the $t$ value for the effect of $\mathrm{CST}^{*}$ as a test of whether regression slopes differed for CST- and CST+ species and used two-tailed significance tests because the difference in slope could plausibly have been in either direction.

\subsection{Population trend vs. CST relationships for species with different ecological traits}

To examine the effects of ecological traits on the relationship of $r$ with CST, we fitted LMMs, with the same random effects structure as above. We did this separately for Europe and the USA because two of the traits (HAB and MIG) had broadly similar, but not precisely equivalent, definitions on the two continents. We had no a priori expectations about the importance of the trait variables, so our model set of interest included all 27 possible models which included the main effect of CST and the main effects of Lmass, HAB and MIG, as well as their two-way interactions with CST (Online Resources 6 and 7). Including two-way interaction terms in this way allowed us to test the effects of trait variables on the slope of the $r$ vs. CST relationship, which was the aim of this analysis. To avoid retention of overly complex models, selection followed the recommendations of Richards et al. (2011) whereby all models with $\triangle \mathrm{AICc}<6$ were classed as a set of top models, excluding models that were more complex versions of those with a lower AICc.

\section{Results}

\subsection{Comparing the $r$ vs. CST relationship for species-states expected to be positively or negatively impacted by climate change}

A significant positive relationship between population trend and CST was found for both species-state groups on both continents (Table 1; Fig. 1). There was no significant difference in the slope of the relationship between population trend and CST between species-states with expected negative (CST-) and positive $(\mathrm{CST}+)$ effects of recent climate change (Table 1; Fig. 1). Hence, there was no statistical support for a weaker

Table 1 Comparison of regression slopes (model coefficients $b$, standard errors SE, and 95\% confidence intervals $95 \%$ CIs) between population trend and climate suitability trend (CST) for species-state populations on the two continents. The regression coefficient $\mathrm{CST}^{*}$ represents the estimated difference in slope between populations expected to be adversely (CST-) or positively affected (CST+) by recent observed climate change. Italicised text indicates results significant at the 0.05 level

\begin{tabular}{|c|c|c|c|c|c|c|}
\hline \multicolumn{2}{|l|}{ Continent } & $b$ & SE & $95 \%$ CIs & $t$ & $P$ \\
\hline \multicolumn{7}{|c|}{ Europe $(n=1686)$} \\
\hline & CST & 0.243 & 0.103 & $0.041-0.445$ & 2.354 & 0.019 \\
\hline & $\mathrm{CST}^{*}$ & -0.240 & 0.185 & $-0.602-0.122$ & -1.298 & 0.195 \\
\hline \multicolumn{7}{|c|}{ USA $(n=6760)$} \\
\hline & CST & 0.186 & 0.069 & $0.050-0.322$ & 2.688 & 0.007 \\
\hline & $\mathrm{CST}^{*}$ & 0.083 & 0.116 & $-0.143-0.310$ & 0.721 & 0.471 \\
\hline
\end{tabular}




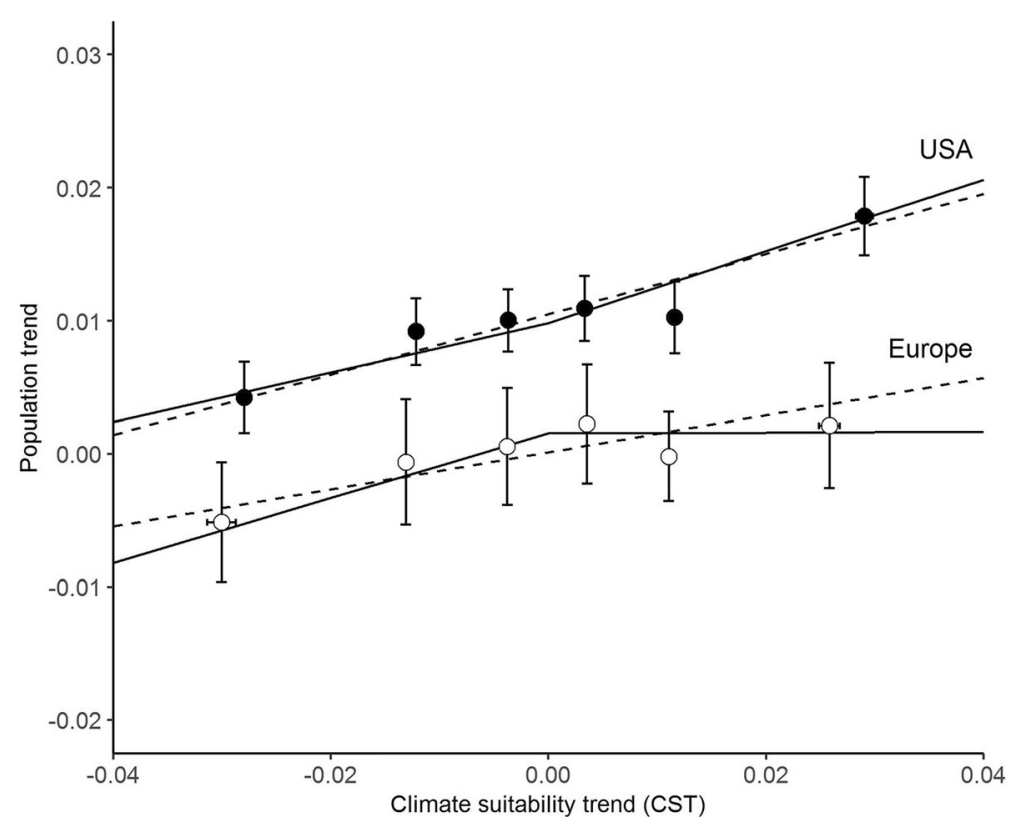

Fig. 1 The effect of climate suitability (CST) on bird population trends $(r)$ for Europe and the USA. Dotted lines represent continent-specific regression models of $r$ on CST from analyses presented by Stephens et al. (2016). Solid lines are those predicted by continent-specific piecewise regression models with a breakpoint at CST $=0$ (see Table 1 for model coefficients). All models also included the random effects of species and state. Plotted points are mean values of population trend and CST ( $\pm 95 \%$ confidence intervals, which are very small for CST) for species-state combinations binned according to their CST value for each continent (species states sorted by descending CST value and grouped into three bins containing approximately equal numbers of CST- speciesstates and three bins containing approximately equal numbers of CST+ species-states: CST- $=284$ and 1263 per bin, $\mathrm{CST}+=278$ and 991 per bin for Europe and the USA respectively)

relationship between observed and expected changes for species expected to be affected negatively by recent change.

\subsection{Effects of ecological traits on the $r$ vs. CST relationship}

For both continents, the top model of the relationship of population trend to CST incorporating ecological and life history traits included the two-way interactions between body mass and CST, and habitat association and CST (Table 2, Online Resources 6, 7 and 8). The main effect of migratory behaviour was also included in the top model for Europe, but not for the USA. Two models were eligible for inclusion in the top set for Europe, whilst four other models were also selected in the top set for the USA. For each continent, the top model set contained various combinations of the variables included in the top model.

The direction and magnitude of the effect of species' body mass on the slope of the regression of population trend on CST differed between continents (Fig. 2, Online Resource 8). For European species, the relationship between the $r$ vs CST regression slope and body mass was negative, so the relationship of $r$ to CST was strongly positive for species of low body mass and became less positive as body mass increased (Fig. 2a), as we hypothesised a priori. However, for birds in the USA, the relationship between the $r$ vs CST regression slope and body mass was positive, so the relationship of $r$ to CST was least positive for species of 
Table 2 Top sets of linear mixed models of population trend in relation to climate suitability trend (CST) and ecological traits of species for Europe and the USA. Both top sets include only those models simpler than the top model with $\triangle \mathrm{AICc}<6$. Models are shown in order of increasing AICc from the top model (shown in italics). Variables included in each model are denoted by codes: HAB broad habitat association, Lmass natural logarithm of body mass in grams. The log likelihood (logLik), number of fitted parameters (df) and Akaike weight (w) are shown for each model. Two-way interaction terms are coded by placing ':' between two variable codes. Results for the full set of models considered are presented in Tables S6 and S7

\begin{tabular}{lllllll}
\hline Continent & Variables retained & logLik & df AICc & \multicolumn{2}{c}{$\Delta$ AICc } & w \\
\hline Europe & CST + Lmass + HAB + MIG + CST:Lmass + CST:HAB & 3043.0 & 20 & -6045.5 & 0.0 & 0.47 \\
& CST + Lmass + HAB + CST:Lmass + CST:HAB & 3040.7 & 18 & -6045.1 & 0.4 & 0.38 \\
USA & CST + Lmass + HAB + CST:Lmass + CST:HAB & $10,861.4$ & $18-21,686.8$ & 0.0 & 0.19 \\
& CST + Lmass + CST:Lmass & $10,855.4$ & 12 & $-21,686.7$ & 0.1 & 0.18 \\
& CST + Lmass + HAB + CST:Lmass & $10,860.1$ & 17 & $-21,686.1$ & 0.6 & 0.14 \\
& CST + Lmass & $10,853.6$ & 11 & $-21,685.2$ & 1.6 & 0.08 \\
\hline
\end{tabular}

low body mass and became more positive as body mass increased (Fig. 2b), counter to our expectation. This contrary effect appears to be driven by the strength of the response of the largest birds on this continent (Fig. 2). When only species of a comparable mass range (10$100 \mathrm{~g}$, spanning the interquartile range of body mass for European species and excluding the heaviest species in the USA, Fig. 2) were included in analysis on both continents, the interaction between $r$ vs CST regression slope and body mass was no longer upheld as important in the top model for the USA, although its effect in Europe remained unchanged (Online Resource 9).
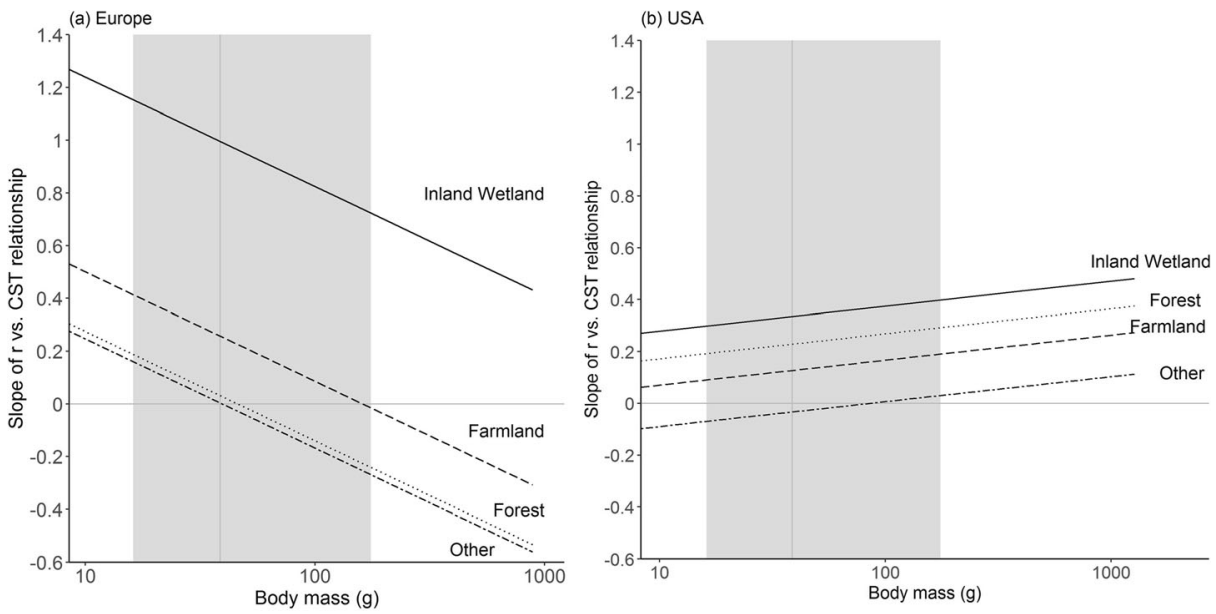

Fig. 2 Regression slopes of the relationship between bird population trends $(r)$ and climate suitability trend (CST) derived from the top model for (a) Europe and (b) the USA. The top models for the two continents both included the main effects of CST, log body mass (Lmass) and habitat and the two-way interactions of CST with each of Lmass and habitat (Table 2, Online Resource 8). Each line shows the modelled slope of the $r$ vs. CST regression in relation to body mass for a single habitat type, with the horizontal extent of the line corresponding to the central $90 \%$ of body mass values for the species studied on each continent. The shaded area shows the interquartile range of body mass and the vertical line its median value. For Europe, the lines for forest and other almost coincide, so for clearer differentiation between these habitats, the line for forest has been jittered upwards by 0.02 (the direction indicated by the model). Line segments lying above the horizontal grey line represent positive modelled relationships between $r$ and CST 
On both continents, species associated with inland wetland had the most positive relationship of $r$ to CST. Species associated with other habitats had the least positive relationship, and relationships for farmland and forest species were of intermediate strength (Fig. 2, Online Resource 8). The slope of the $r$ vs CST regression was positive across the whole of the observed range of body mass for species associated with inland wetland in Europe and for species associated with inland wetland, farmland and forest in the USA. It was also positive across most of the observed range of body mass for species associated with farmland, forest and other habitats in Europe but not for species associated with other habitat in the USA.

\section{Discussion}

Our analyses of over 500 bird species confirm the overall positive relationship between population trend and climate suitability on our two focal continents in support of Stephens et al. (2016) and others (Green et al. 2008; Gregory et al. 2009). Importantly, we found no statistically supported difference in the strength of the relationship between population trend and climate suitability change between those species expected to benefit from climate change and those expected to be adversely impacted, failing to support previous reports that the positive effects of climate change have been more pronounced than its negative effects. Across our sample of 525 species over the two continents, we therefore found no strong evidence of a greater tendency for delay in effects of climate change on species' populations projected to be negatively impacted compared to those projected to be positively impacted by climate, in contrast to suggestions from previous, often finerscale studies (e.g. see Thomas et al. 2006). The positive relationship between population trend and climate suitability largely persisted regardless of species ecology, although the strength of relationship varied with ecological traits, further increasing the causal evidence of a consistent effect of climate change on bird populations over recent decades.

It has been suggested that the evidence for negative population responses to climate change may be less strong than for positive population responses (e.g. Parmesan et al. 1999; Parmesan and Yohe 2003; Root et al. 2003; Thomas and Lennon 1999). However, our evidence of a positive relationship between population trend and CST was, if anything, more compelling for species-states expected to be negatively impacted rather than those expected to benefit (Fig. 1). A similar study examining community composition found a similar effect of comparable contributions of both cold-dwelling ( $\sim$ CST-) and warm-dwelling $(\sim \mathrm{CST}+)$ species to regional climate-induced changes across a smaller geographic area (Tayleur et al. 2016). A possible explanation for why we found no evidence that species favoured by changing climate suitability have responded more strongly than species expected to be disadvantaged, may be that we compared range change predictions from models of distribution data with detailed abundance data in our analyses. Assessments of climate impact based on distribution data alone are more likely to be biased towards increases in range which are often more noticeable (Thomas and Abery 1995; Thomas et al. 2006), whilst abundance data from long-term population monitoring schemes, by being more sensitive to changes than range, are unlikely to share this bias. This therefore stresses the importance of long-term population monitoring schemes over simple spatial occupancy data for detecting large-scale species' responses to environmental changes. Our assumption of a linear relationship between population trends and climate suitability may have resulted in our analysis being less able to capture the nature of the relationship. Developing theory to guide understanding of the relationship between population trends and climate suitability would provide a useful area of future research. 
The population trend vs. CST relationship was slightly less positive for CST+ species in Europe than the other groups tested, indicating that this group may be less able to take advantage of an increasingly suitable climate. This may reflect differences in the underlying trajectories of avian abundance between the two continents, with average trends in Europe predominantly negative since 1980 (EBCC 2014), whilst US bird populations have, on average, remained relatively stable (Sauer and Link 2011; Stephens et al. 2016). This is reflected in the lower mean values of population trend at a given value of CST in Europe compared to the USA evident in Fig. 1. These different patterns could be related to the proportion of rare species included in population monitoring data for the two continents. In Europe, rarer species have been faring better than more common species (Inger et al. 2015) but our European dataset is focussed on common birds (PECBMS 2012). Differences in land-use change on the two continents (Clavero et al. 2011; Kampichler et al. 2012), both in terms of current rates of change and levels of historical conversion, might also have a bearing on mean population trajectories.

Another explanation for why CST+ species may not be responding as positively in terms of population trend in Europe is if they are following the pattern of increasing climate suitability into an ecological trap due to changing land use and intensity patterns (Herrando et al. 2014). This could be the case if pressures other than climate change, such as agricultural intensification or land abandonment, were particularly prevalent in Europe compared to the USA (e.g. Lasanta et al. 2017).

The strength of the relationship between population trend and climate suitability varied in relation to the same ecological traits on both continents, with similar patterns found for species associated with different habitat types; associations with body mass, however, were more complex. It has been proposed that a warming climate favours smaller species (Atkinson 1994; Millien et al. 2006; Sheridan and Bickford 2011), and distribution shifts driven by climate change may be stronger in small-bodied species with more rapid reproduction and shorter generations (Devictor et al. 2012), so we expected that smaller species would respond more positively to warming climate and associated range changes. In accord with this hypothesis, we found that species with smaller body mass had a more positive population trend to CST relationship, but only in Europe.

In the USA, we found the opposite effect of body mass on the population trend to CST relationship, with larger species apparently having more positive population trend vs. CST relationships. This relationship was not supported when we considered equivalent mass ranges $(10-100 \mathrm{~g})$ of species on both continents however, suggesting that it is driven by strong responses to climate change among the very largest species in the USA. The reasons for this finding are unclear but could be explained by the inclusion of large bodied wetland species in our US dataset, which, as discussed below, appear to be more responsive to environmental change. Similar large bodied wetland species are absent from our European data set, potentially explaining the discrepancies in these results.

As hypothesised, species associated with different breeding habitats responded differently to changes in climate suitability, and these responses were largely consistent on both continents. Species associated with inland wetlands showed a consistently more positive relationship between $r$ and CST than those associated with other habitat types. The biota of wetlands may be more responsive to environmental changes due to the already seasonal or stochastic 
nature and spatial or temporal patchiness of wetland habitats relative to less labile ecosystems (e.g. forests), which can withstand environmental changes for many decades without exhibiting large-scale community changes (Erwin 2009; Lindner et al. 2010). Wetland breeding birds may also make longer-distance dispersal movements than those associated with dry habitats for the same reason (Paradis et al. 1998), so they may be better able to respond more rapidly to changing conditions. Strong and increasing protection of wetlands relative to other habitats, at least in Europe (Butchart et al. 2012), may also allow wetland bird populations to better track the direction of climate suitability without the trade-off of also adapting to habitat change and other threats (Gaüzère et al. 2016). These habitat changes and threats may also be more coherent with the impact of climatic changes (e.g. drainage and water abstraction similar to the drying effects of reduced rainfall and warmer temperatures; Erwin 2009), potentially explaining the enhanced the strength of the $r$ and CST relationship for wetland species.

Surprisingly, migratory behaviour was not found to be important in affecting the strength of the relationship between population trend and CST on either continent. Long-distance migrants are less able to adapt their phenology than their resident and short-distance migrant counterparts. Phenological mismatch renders long-distance migrants vulnerable to the effects of worsening climate suitability across their breeding grounds, whilst also rendering them less able to benefit from improvements in climate suitability (Both et al. 2010; Franks et al. 2018; Mayor et al. 2017; Samplonius et al. 2018; Vickery et al. 2014). In addition, the effects of phenological mismatch vary between species, study systems and habitats (Both et al. 2010; Hurlbert and Liang 2012). With potentially contrasting responses by migratory species to changes in climate suitability, the effect of migratory behaviour on the $r$ vs CST relationship may be weaker than expected.

Taken together, our results indicate that ecological traits and habitat associations substantially affect the strength of bird population responses to changing climate suitability, but that their impact may not always be consistent even between continents. Much emphasis is currently placed on examining the likely impacts of ecological traits on species' responses to climate change, with the aim of predicting global patterns of climate change adaption (e.g. Angert et al. 2011; Jiguet et al. 2007; Jiguet et al. 2010; Pearson et al. 2014). Our results suggest that generalizing the impacts of these traits from localised geographical studies, even those examining whole continents, to a universal scale may not be robust.

Thomas et al. (2006) highlighted the likely artefactual perception that range expansions and population increases as a result of climate change are more widespread than range retractions and population decreases. Here, we have shown that despite differences in species ecology, the relationship between population trend and climate suitability trend is persistently positive across an entire taxonomic group and two continents, with no evidence that species favoured by climate change have responded more strongly than those disadvantaged by it, thus providing clear evidence that climate change is causing widespread strong, quantifiable population increases and declines in equal measures.

Acknowledgements The data used are held by individual institutes and collated by the United States Geological Survey and European Bird Census Council. We acknowledge the tremendous fieldwork effort made by volunteers on both continents in gathering bird data, and thank all PECBMS national data providers. Stuart Butchart (Birdlife International) provided valuable comments on the manuscript.

Funding information This work was part-funded by the Royal Society for the Protection of Birds, the European Environment Agency, the European Commission, and Durham University Grevillea Trust. 
Open Access This article is distributed under the terms of the Creative Commons Attribution 4.0 International License (http://creativecommons.org/licenses/by/4.0/), which permits unrestricted use, distribution, and reproduction in any medium, provided you give appropriate credit to the original author(s) and the source, provide a link to the Creative Commons license, and indicate if changes were made.

\section{References}

Angert AL, Crozier LG, Rissler LJ, Gilman SE, Tewksbury JJ, Chunco AJ (2011) Do species' traits predict recent shifts at expanding range edges? Ecol Lett 14:677-689

Araújo MB, New M (2007) Ensemble forecasting of species distributions. Trends Ecol Evol 22:42-47

Araujo MB, Pearson RG, Thuiller W, Erhard M (2005) Validation of species-climate impact models under climate change. Glob Chang Biol 11:1504-1513

Araújo MB, Alagador D, Cabeza M, Nogués Bravo D, Thuiller W (2011) Climate change threatens European conservation areas. Ecol Lett 14:484-492

Atkinson D (1994) Temperature and organism size a biological law for ectotherms? Adv Ecol Res 25:1-58. https://doi.org/10.1016/S0065-2504(08)60212-3

Bagchi R, Crosby M, Huntley B, Hole DG, Butchart SHM, Collingham Y, Kalra M, Rajkumar J, Rahmani A, Pandey M, Gurung H, Trai LT, Van Quang N, Willis SG (2013) Evaluating the effectiveness of conservation site networks under climate change: accounting for uncertainty. Glob Chang Biol 19:1236-1248

Barbet-Massin M, Thuiller W, Jiguet F (2010) How much do we overestimate future local extinction rates when restricting the range of occurrence data in climate suitability models? Ecography 33:878-886

Bates D, Maechler M (2009) lme4: linear mixed-effects models using S4 classes. http://CRAN.R-project. org/package=lme4

BirdLife International Natureserve (2013) Bird species distribution maps of the world. Version 3.0. BirdLife International, Cambridge

BirdLife-International (2014) World bird database. http://www.birdlife.org/datazone/home

Both C, Van Turnhout CA, Bijlsma RG, Siepel H, Van Strien AJ, Foppen RP (2010) Avian population consequences of climate change are most severe for long-distance migrants in seasonal habitats. Proc $\mathrm{R}$ Soc B Biol Sci 277:1259-1266

Brommer JE, Lehikoinen A, Valkama J (2012) The breeding ranges of central European and Arctic bird species move poleward. PLoS One 7:e43648

Buckley LB, Kingsolver JG (2012) Functional and phylogenetic approaches to forecasting species' responses to climate change. Annu Rev Ecol Evol Syst 43

Butchart SH, Scharlemann JP, Evans MI, Quader S, Arico S, Arinaitwe J, Balman M, Bennun LA, Bertzky B, Besancon C (2012) Protecting important sites for biodiversity contributes to meeting global conservation targets. PLoS One 7:e32529

Clavero M, Villero D, Brotons L (2011) Climate change or land use dynamics: do we know what climate change indicators indicate? PLoS One 6:e18581

Cramp S, Simmons AD, Perrins CM (eds) (1977-1994) Handbook of the birds of Europe, the middle East and North Africa. Volumes I-IX, Oxford University Press

Cutler DR, Edwards TCJ, Beard KH, Cutler A, Hess KT (2007) Random forests for classification in ecology. Ecology 88:2783-2792

Devictor V, van Swaay C, Brereton T, Brotons L, Chamberlain D, Heliola J, Herrando S, Julliard R, Kuussaari M, Lindstrom A, Reif J, Roy DB, Schweiger O, Settele J, Stefanescu C, Van Strien A, Van Turnhout C, Vermouzek Z, WallisDeVries M, Wynhoff I, Jiguet F (2012) Differences in the climatic debts of birds and butterflies at a continental scale. Nat Clim Chang 2:121-124

EBCC (2014) http://www.ebcc.info/index.php?ID=510

Elith J, Leathwick JR (2009) Species distribution models: ecological explanation and prediction across space and time. Annu Rev Ecol Evol Syst 40:677-697

Elith J, Leathwick JR, Hastie T (2008) A working guide to boosted regression trees. J Anim Ecol 77:802-813

Engler JO, Stiels D, Schidelko K, Strubbe D, Quillfeldt P, Brambilla M (2017) Avian SDMs: current state, challenges, and opportunities. J Avian Biol 48:1483-1504

Erwin KL (2009) Wetlands and global climate change: the role of wetland restoration in a changing world. Wetl Ecol Manag 17:71-84

Foden W, Mace GM, Vié J-C, Angulo A, Butchart SHM, DeVantier L, Dublin H, Gutsche A, Stuart S, Turak E (2009) Species susceptibility to climate change impacts. In: Vié J-C, Hilton-Taylor C, Stuart SN (eds) Wildlife in a changing world - an analysis of the 2008 IUCN Red List of threatened species. IUCN, Gland, pp 77-87 
Franklin J (2009) Mapping species distributions. Cambridge University Press, Cambridge

Franks SE, Pearce-Higgins JW, Atkinson S, Bell JR, Botham MS, Brereton TM, Harrington R, Leech DI (2018) The sensitivity of breeding songbirds to changes in seasonal timing is linked to population change but cannot be directly attributed to the effects of trophic asynchrony on productivity. Glob Chang Biol 24:957-971

Frishkoff LO, Karp DS, Flanders JR, Zook J, Hadly EA, Daily GC, M'Gonigle LK (2016) Climate change and habitat conversion favour the same species. Ecol Lett 19:1081-1090

Gaüzère P, Jiguet F, Devictor V (2016) Can protected areas mitigate the impacts of climate change on bird's species and communities? Divers Distrib 22:625-637

Green RE, Collingham YC, Willis SG, Gregory RD, Smith KW, Huntley B (2008) Performance of climate envelope models in retrodicting recent changes in bird population size from observed climatic change. Biol Lett 4:599-602

Gregory RD, Willis SG, Jiguet F, Vořǐšek P, Klaňová A, Av S, Huntley B, Collingham YC, Couvet D, Green RE (2009) An indicator of the impact of climatic change on European bird populations. PLoS One 4:e4678

Hagemeijer WJ, Blair MJ (1997) The EBCC atlas of European breeding birds: their distribution and abundance. Poyser, London

Hardy MA (1993) Regression with dummy variables. Sage University Paper series on Quantitive Applications in the Social Sciences, 07-093. Sage, Newbury Park

Harris I, Jones PD, Osborn TJ, Lister DH (2014) Updated high-resolution grids of monthly climatic observations - the CRU TS3.10 Dataset. Int J Climatol 34:623-642

Hastie TJ, Tibshirani R (1990) Generalized additive models. Chapman and Hall, London

Herrando S, Anton M, Sardà-Palomera F, Bota G, Gregory RD, Brotons L (2014) Indicators of the impact of land use changes using large-scale bird surveys: land abandonment in a Mediterranean region. Ecol Indic 45:235244

Hickling R, Roy DB, Hill JK, Fox R, Thomas CD (2006) The distributions of a wide range of taxonomic groups are expanding polewards. Glob Chang Biol 12:450-455

Hijmans RJ, Cameron SE, Parra JL, Jones PG, Jarvis A (2005) Very high resolution interpolated climate surfaces for global land areas. Int J Climatol 25:1965-1978

Huntley B, Green RE, Collingham YC, Willis SG (2007) A climatic atlas of European breeding birds. Durham University, The RSPB and Lynx Edicions, Barcelona

Hurlbert AH, Liang Z (2012) Spatiotemporal variation in avian migration phenology: citizen science reveals effects of climate change. PLoS One 7:e31662

Inger R, Gregory R, Duffy JP, Stott I, Voříšek P, Gaston KJ (2015) Common European birds are declining rapidly while less abundant species' numbers are rising. Ecol Lett 18:28-36

Jiguet F, Gadot A-S, Julliard R, Newson SE, Couvet D (2007) Climate envelope, life history traits and the resilience of birds facing global change. Glob Chang Biol 13:1672-1684

Jiguet F, Gregory RD, Devictor V, Green RE, Voříšek P, Van Strien A, Couvet D (2010) Population trends of European common birds are predicted by characteristics of their climatic niche. Glob Chang Biol 16:497505

Kampichler C, Van Turnhout CA, Devictor V, Van Der Jeugd HP (2012) Large-scale changes in community composition: determining land use and climate change signals. PLoS One 7:e35272

Kuussaari M, Bommarco R, Heikkinen RK, Helm A, Krauss J, Lindborg R, Öckinger E, Pärtel M, Pino J, Roda F (2009) Extinction debt: a challenge for biodiversity conservation. Trends Ecol Evol 24:564-571

Lasanta T, Arnáez J, Pascual N, Ruiz-Flaño P, Errea M, Lana-Renault N (2017) Space-time process and drivers of land abandonment in Europe. Catena 149:810-823

Lehikoinen A, Brotons L, Calladine J, Campedelli T, Escandell V, Flousek J, Grueneberg C, Haas F, Harris S, Herrando S, Husby M, Jiguet F, Kålås JA, Lindström Å, Lorrillière R, Molina B, Pladevall C, Calvi G, Sattler T, Schmid H, Sirkiä PM, Teufelbauer N, Trautmann S (2019) Declining population trends of European mountain birds. Glob Chang Biol 25:577-588

Lindner M, Maroschek M, Netherer S, Kremer A, Barbati A, Garcia-Gonzalo J, Seidl R, Delzon S, Corona P, Kolström M (2010) Climate change impacts, adaptive capacity, and vulnerability of European forest ecosystems. For Ecol Manag 259:698-709

Mayor SJ, Guralnick RP, Tingley MW, Otegui J, Withey JC, Elmendorf SC, Andrew ME, Leyk S, Pearse IS, Schneider DC (2017) Increasing phenological asynchrony between spring green-up and arrival of migratory birds. Sci Rep 7:1902

McCullagh P, Nelder JA (1989) Generalized linear models. Chapman and Hall, London

Menéndez R, Megías AG, Hill JK, Braschler B, Willis SG, Collingham Y, Fox R, Roy DB, Thomas CD (2006) Species richness changes lag behind climate change. Proc R Soc Lond B Biol Sci 273:1465-1470

Meynard CN, Quinn JF (2007) Predicting species distributions: a critical comparison of the most common statistical models using artificial species. J Biogeogr 34:1455-1469 
Millien V, Kathleen Lyons S, Olson L, Smith FA, Wilson AB, Yom-Tov Y (2006) Ecotypic variation in the context of global climate change: revisiting the rules. Ecol Lett 9:853-869

Paradis E, Baillie SR, Sutherland WJ, Gregory RD (1998) Patterns of natal and breeding dispersal in birds. J Anim Ecol 67:518-536

Parmesan C, Yohe G (2003) A globally coherent fingerprint of climate change impacts across natural systems. Nature 421:37-42

Parmesan C, Ryrholm N, Stefanescu C, Hill JK, Thomas CD, Descimon H, Huntley B, Kaila L, Kullberg J, Tammaru T (1999) Poleward shifts in geographical ranges of butterfly species associated with regional warming. Nature 399:579

Pearce-Higgins JW, Green RE (2014) Birds and climate change: impacts and conservation responses. Cambridge University Press, Cambridge

Pearce-Higgins JW, Ockendon N, Baker DJ, Carr J, White EC, Almond REA, Amano T, Bertram E, Bradbury RB, Bradley C, Butchart SHM, Doswald N, Foden W, Gill DJC, Green RE, Sutherland WJ, Tanner EVJ (2015) Geographical variation in species' population responses to changes in temperature and precipitation. Proc R Soc Lond B Biol Sci 282:20151561

Pearson RG, Stanton JC, Shoemaker KT, Aiello-Lammens ME, Ersts PJ, Horning N, Fordham DA, Raxworthy CJ, Ryu HY, McNees J (2014) Life history and spatial traits predict extinction risk due to climate change. Nat Clim Chang 4:217

PECBMS (2012) http://www.ebcc.info/indebothx.php?ID=491

Poole A (2005) The birds of North America online: http://bna.birds.cornell.edu/BNA/. Cornell Laboratory of Ornithology, Ithaca, NY

Prentice I, Cramer W, Harrison SP, Leemans R, Monserud RA, Solomon AM (1992) A global biome model based on plant physiology and dominance, soil properties and climate. J Biogeogr 19:117-134

R Core Team (2013) R: a language and environment for statistical computing. R Foundation for Statistical Computing, Vienna, Austria. http://www.R-project.org/version 3.0.2

Richards SA, Whittingham MJ, Stephens PA (2011) Model selection and model averaging in behavioural ecology: the utility of the IT-AIC framework. Behav Ecol Sociobiol 65:77-89

Root TL, Price JT, Hall KR, Schneider SH, Rosenzweig C, Pounds JA (2003) Fingerprints of global warming on wild animals and plants. Nature 421:57-60

Samplonius JM, Bartošová L, Burgess MD, Bushuev AV, Eeva T, Ivankina EV, Kerimov AB, Krams I, Laaksonen T, Mägi M (2018) Phenological sensitivity to climate change is higher in resident than in migrant bird populations among European cavity breeders. Glob Chang Biol 24:3780-3790

Sanderson FJ, Donald PF, Pain DJ, Burfield IJ, Van Bommel FP (2006) Long-term population declines in AfroPalearctic migrant birds. Biol Conserv 131:93-105

Sauer JR, Link WA (2011) Analysis of the North American Breeding Bird Survey using hierarchical models. Auk 128:87-98

Sheridan JA, Bickford D (2011) Shrinking body size as an ecological response to climate change. Nat Clim Chang 1:401-406

Snow D, Perrins C (1998) The birds of the Western Palaearctic: concise edition. Oxford University Press, UK

Speek BJ, Speek G (1984) Thieme's vogeltrekatlas: terugmeldingen van 181 vogelsoorten verzameld in 301 geografische kaarten. Thieme, Zutphen. [Dutch migration atlas]

Spina F, Volponi S (2008-2009) Atlante della Migrazione degli Uccelli in Italia. Vol. 1-2. ISPRA - MATTM, Rome

Spooner FEB, Pearson RG, Freeman R (2018) Rapid warming is associated with population decline among terrestrial birds and mammals globally. Glob Change Biol 24:4521-4531. https://doi.org/10.1111/gcb.14361

Stephens PA, Mason LR, Green RE, Gregory RD, Sauer JR, Alison J, Aunins A, Brotons L, Butchart SHM, Campedelli T, Chodkiewicz T, Chylarecki P, Crowe O, Elts J, Escandell V, Foppen RPB, Heldbjerg H, Herrando S, Husby M, Jiguet F, Lehikoinen A, Lindström Å, Noble DG, Paquet J-Y, Reif J, Sattler T, Szép T, Teufelbauer N, Trautmann S, van Strien AJ, van Turnhout CAM, Vorisek P, Willis SG (2016) Consistent response of bird populations to climate change on two continents. Science 352:84-87

Tayleur CM, Devictor V, Gaüzère P, Jonzén N, Smith HG, Lindström A (2016) Regional variation in climate change winners and losers highlights the rapid loss of cold-dwelling species. Divers Distrib 22:468-480

Thomas C, Abery J (1995) Estimating rates of butterfly decline from distribution maps: the effect of scale. Biol Conserv 73:59-65

Thomas CD, Lennon JJ (1999) Birds extend their ranges northwards. Nature 399:213

Thomas CD, Franco AM, Hill JK (2006) Range retractions and extinction in the face of climate warming. Trends Ecol Evol 21:415-416

Tucker GM, Evans MI (1997) Habitats for birds in Europe: a conservation strategy for the wider environment. BirdLife International, Cambridge 
Vickery JA, Ewing SR, Smith KW, Pain DJ, Bairlein F, Škorpilová J, Gregory RD (2014) The decline of AfroPalaearctic migrants and an assessment of potential causes. Ibis 156:1-22

Visser M, Adriaensen F, Van Balen J, Blondel J, Dhondt A, Van Dongen S, Du Feu C, Ivankina E, Kerimov A, De Laet J (2003) Variable responses to large-scale climate change in European Parus populations. Proc R Soc B Biol Sci 270:367-372

Wenger SJ, Olden JD (2012) Assessing transferability of ecological models: an underappreciated aspect of statistical validation. Methods Ecol Evol 3:260-267

Wernham C, Toms M, Marchant J, Clark J, Siriwardena G, Baillie S (2002) The migration atlas: movements of the birds of Britain and Ireland. T \& AD Poyser, London

Zink G, Bairlein F (1987-1995) Der Zug Europäischer Singvögel: Atlas der Wiederfunde Beringter Vögel Band 1-3. Aula Verlag, Wiesbaden

Publisher's note Springer Nature remains neutral with regard to jurisdictional claims in published maps and institutional affiliations.

\section{Affiliations}

Lucy R. Mason ${ }^{1} \cdot$ Rhys E. Green ${ }^{1,2} \cdot$ Christine Howard $^{3} \cdot$ Philip A. Stephens $^{3} \cdot$ Stephen G. Willis ${ }^{3}$ - Ainars Aunins ${ }^{4,5}$ - Lluís Brotons ${ }^{6,7,8,9}$ - Tomasz Chodkiewicz ${ }^{10,11}$. Przemysław Chylarecki ${ }^{10}$ • Virginia Escandell ${ }^{12}$ - Ruud P. B. Foppen ${ }^{13,14,15}$ • Sergi Herrando $^{6,7}$ - Magne Husby ${ }^{16,17}$ • Frédéric Jiguet ${ }^{18}$ • John Atle Kålås ${ }^{19}$ • Åke Lindström $^{20}$. Dario Massimino ${ }^{21} \cdot{\text { Charlotte Mosh } ø j^{22}}^{22}$ Renno Nellis ${ }^{23}$ • Jean-Yves Paquet $^{24}$ • Jiří Reif ${ }^{25}$ • Päivi M. Sirkiä ${ }^{26}$ - Tibor Szép ${ }^{27}$ • Guido Tellini Florenzano ${ }^{28}$. Norbert Teufelbauer $^{29}$. Sven Trautmann ${ }^{30}$ - Arco van Strien ${ }^{31}$ - Chris A. M. van Turnhout $^{13,14}$ • Petr Voříšek ${ }^{32,33}$ • Richard D. Gregory ${ }^{1,34}$

1 RSPB Centre for Conservation Science, The Lodge, Sandy, Bedfordshire SG19 2DL, UK

2 Conservation Science Group, Department of Zoology, University of Cambridge, David Attenborough Building, Pembroke Street, Cambridge CB2 3QZ, UK

3 Conservation Ecology Group, Department of Biosciences, Durham University, South Road, Durham DH1 3LE, UK

4 Faculty of Biology, University of Latvia, Jelgavas iela 1, Riga LV-1004, Latvia

5 Latvian Ornithological Society, Skolas iela 3, Riga LV-1010, Latvia

6 Catalan Ornithological Institute, Natural History Museum of Barcelona, Plaça Leonardo da Vinci 4-5, 08019 Barcelona, Catalonia, Spain

7 CREAF, 08193 Cerdanyola del Vallès, Spain

8 InForest Jru (CTFC-CREAF), Crta. Antiga St Llorenç de Morunys km 2, 25280 Solsona, Catalonia, Spain

9 CSIC, Cerdanyola del Vallès, Spain

10 Museum \& Institute of Zoology, Polish Academy of Sciences, Wilcza 64, 00-679 Warszawa, Poland

11 Polish Society for the Protection of Birds, Odrowąża 24, 05-270 Marki, Poland

12 Sociedad Española de Ornitología/BirdLife Melquiades Biencinto, 34, 28053 Madrid, Spain

13 Sovon Dutch Centre for Field Ornithology, 6503, Nijmegen, The Netherlands

14 Department of Animal Ecology and Ecophysiology, Institute for Water and Wetland Research, Radboud University, 6500, Nijmegen, The Netherlands

15 European Bird Census Council, Post Office Box 6521, 6503 GA Nijmegen, Netherlands

16 Nord University, Røstad, 7600 Levanger, Norway

17 BirdLife Norway, Sandgata 30B, 7012 Trondheim, Norway 
18 MNHN, CRBPO, UMR7204 CESCO, Equipe Conservation et Restauration des Populations (CORPO), 43 rue Buffon, 75005 Paris, France

19 Norwegian Institute for Nature Research, P.O. Box 5685, Torgarden, NO-7485 Trondheim, Norway

20 Biodiversity Unit, Department of Biology, Lund University, SE-223 62 Lund, Sweden

21 British Trust for Ornithology, The Nunnery, Thetford IP24 2PU, UK

22 Dansk Ornitologisk Forening (BirdLife Denmark), Vesterbrogade 140, 1620 Copenhagen V, Denmark

23 Estonian Ornithological Society, Birdlife Estonia, Veski 4, Tartu, Estonia

24 Natagora, Département Études, Traverse des Muses 1, B-5000 Namur, Belgium

25 Institute for Environmental Studies, Faculty of Science, Charles University, Benatska 2, 12801 Prague, Praha 2, Czech Republic

26 Zoology unit, Finnish Museum of Natural History, University of Helsinki, FI-00014 Helsinki, Finland

27 Institute of Environmental Sciences, University of Nyíregyháza, Sóstói út 31/b, Nyíregyháza 4401, Hungary

28 Dream Italia, via R. Scoti 30, I-52011, Bibbiena, AR, Italy

29 BirdLife Österreich, Museumsplatz 1/10/7-8, A-, 1070 Vienna, Austria

30 Dachverband Deutscher Avifaunisten e.V. (Federation of German Avifaunists), An den Speichern 6, 48157 Münster, Germany

31 Statistics Netherlands, Post Office Box 24500, 2490 HA The Hague, Netherlands

32 Pan-European Common Bird Monitoring Scheme, Czech Society for Ornithology, Na Bělidle 34, CZ-, 150 00 Prague 5, Czech Republic

33 Department of Zoology and Laboratory of Ornithology, Faculty of Science, Palacký University in Olomouc, 17. listopadu 50, 77143 Olomouc, Czech Republic

34 Centre for Biodiversity \& Environment Research, Department of Genetics, Evolution and Environment, University College London, Darwin Building, Gower Street, London WC1E 6BT, UK 